\title{
Diversity and Distribution of Rice Blast (Pyricularia oryzae Cavara) Races in Vietnam
}

\author{
Nguyen T. M. Nguyet, ${ }^{1}$ Hoang H. Long, ${ }^{1}$ Nguyen B. Ngoc, ${ }^{1}$ Nguyen T Nhai, ${ }^{1}$ Nguyen T. T. Thuy, ${ }^{2}$ Nagao Hayashi, ${ }^{3}$ \\ and Yoshimichi Fukuta ${ }^{4, \dagger}$ \\ ${ }^{1}$ Agricultural Genetics Institute, Km, Pham Van Dong, Bac Tu Liem, Hanoi, Vietnam \\ 2 Vietnam Agriculture and Rural Development Ministry, Ngoc Ha, Ba Dinh, Hanoi, Vietnam \\ ${ }^{3}$ Institute of Agrobiological Sciences, National Agricultural and Food Research Organization, Tsukuba, Ibaraki 305-8602, Japan \\ ${ }^{4}$ Tropical Agricultural Research Front, Japan International Research Center for Agricultural Sciences, Maezato, Ishigaki, Oki- \\ nawa 907-0002, Japan
}

\begin{abstract}
A total of 239 isolates of blast (Pyricularia oryzae Cavara) collected from northern and central Vietnam showed a wide variation in pathogenicity based on the reaction patterns to 25 differential varieties (DVs) harboring 23 resistance genes and susceptible cultivar Lijiangxintuanheigu (LTH). The frequencies of isolates virulent toward DVs for Pish, Pik-m, Pil, Pikh, Pik, Pik-p,Pi7(t), Pi9(t), Piz-5, Pita-2, and Pita were low, but they were high for DVs for Pib, Pit, Pia, Pii, Pi3, Pi5(t), Pik-s, Piz, Piz-t, $P i 12(\mathrm{t}), P i 19(\mathrm{t})$, and $P i 20(\mathrm{t})$. Isolates were classified into three cluster groups Ia, Ib, and II based on reaction patterns to DVs and LTH. The fre-

The frequencies to DVs for Pii, Pi3, Pi5(t), and Piz- $t$ were different between clusters Ia and Ib. Clusters Ia and Ib were distributed with similar frequencies in the northeast, north central, and south central coast regions, but the frequencies among three cluster groups in the Red River Delta and northwest regions were different. This means that the blast races in these two regions were different from the others. Overall, the blast isolates were categorized into 153 races. Among them, 26 were selected as a set of standard differential blast isolates for characterizing 23 resistance genes and developing a differential system in Vietnam.
\end{abstract} quencies of isolates virulent toward 11 DVs for Pik-m, Pil, Pik-h, Pik, Pik-p,Pi7(t), Pi9(t), Piz, Piz-5, Pita-2, and Pita in cluster II and DV for Piz- $t$ were higher and lower than those of Ia and Ib, respectively.
Keywords: blast (Pyricularia oryzae Cavara), rice (Oryza sativa L.), race, Vietnam, variation
Rice blast, caused by the pathogen Pyricularia oryzae Cavara, is one of the most serious diseases affecting rice (Oryza sativa L.) production worldwide (Zeigler et al. 1994). In Vietnam, Sang et al. (1996) reported that blast has become a major disease afflicting rice in the Mekong River Delta. Noda et al. (1999) indicated that, although blast disease was not a problem when local rice cultivars were cultivated using traditional agriculture practices, blast often caused severe damage to rice production after the early 1980s when improved cultivars, such as cultivars IR 36, MTL30, and MYL36, were introduced.

The most economical method to control blast disease in rice is the use of resistant cultivars. However, using such cultivars is effective only for a limited time owing to the breakdown of resistance genes as more virulent races of blast occur. The interaction between host resistance and blast fungus virulence can be explained by the genefor-gene theory: every resistance gene in the host corresponds to an avirulence gene in the pathogen (Flor 1971; Silué et al. 1992). On the basis of this theory, differential varieties (DVs) have been developed that can be used to distinguish pathotypes (races) by the patterns of reaction to each strain of pathogen and that can be used to identify blast pathogen population structures.

Tsunematsu et al. (2000) developed 25 monogenic rice lines as a set of international DVs harboring 23 kinds of resistance gene: Pish, Pib, Pit, Pia, Pii, Pi3, Pi5(t), Pik-s, Pik-m, Pil, Pik-h, Pik, Pik-p, Pi7(t), Pi9(t), Piz, Piz-5, Piz-t, Pita-2, Pita,Pi12(t), Pi19(t), and

${ }^{\dagger}$ Corresponding author: Y. Fukuta; zen@affrc.go.jp

*The $\boldsymbol{e}$-Xtra logo stands for "electronic extra" and indicates that one supplementary figure and one supplementary table are published online.

The author(s) declare no conflict of interest.

Accepted for publication 2 September 2019

(C) 2020 The American Phytopathological Society
Pi20(t). These monogenic lines were produced by introducing single resistance genes into the genetic background of a Chinese Japonica Group rice cultivar Lijiangxintuanheigu (LTH). For more advanced DVs, Telebanco-Yanoria et al. (2010) bred near-isogenic lines (NILs) of LTH harboring 11 resistance genes: Pib, Piz-5, Pi9(t), Pi3, Pia, Pik-s, Pik, Pik-h, Pi7(t), Pita, and Pita-2. These monogenic lines and the LTH NILs are minimally influenced by the genetic background and are the most effective materials for use as international DVs. Hayashi and Fukuta (2009) proposed a new international system for the designation of virulent blast isolates by using these monogenic lines. In that system, blast isolates are designated by the reaction patterns of LTH and the 25 monogenic lines harboring the 23 resistance genes.

By using this set of international DVs and the new designation system, the pathogenicities of blast isolates have been evaluated, and their races have been clarified in Cambodia (Fukuta et al. 2014), West Africa (Odjo et al. 2014), Japan (Kawasaki-Tanaka et al. 2016), and Bangladesh (Khan et al. 2016). Evaluation by using a set of international DVs and a system of designation of blast isolates allows comparison of information from different countries or regions as common tools. A differential system consisting of DVs and standard differential blast isolates (SDBIs), with pathogenicities that were clarified based on their reaction patterns with respect to DVs, was developed in these studies. Such a differential system can be useful as a basic tool for blast studies for identifying the virulence of blast isolates and identifying resistance gene(s) in rice cultivars.

In Vietnam, Noda et al. (1999) collected 129 blast isolates from the Mekong River Delta in 1995 and 1996, and they characterized the isolates into 12 pathogenic races by using 12 Japanese DVs (Kiyosawa 1984). They found that high frequencies of isolates (86.0 to $65.3 \%$ ) were virulent toward DVs for Pia, Pit, and Pik-s, and they also found that $38 \%$ of isolates were virulent to DVs for Pita and Pii. They found isolates nonvirulent toward DVs, including Piz-t, Pik-p, and Pish. They suggested that Pish or an unknown gene in the genetic backgrounds of the Japanese DVs complicated the results and limited the value of the Japanese DVs for use in studies 
of pathogenicity. Nguyen et al. (2015) collected blast isolates from the south central coast of Vietnam and found high frequencies of blast isolates virulent toward the set of monogenic rice lines developed by Tsunematsu et al. (2000) as international DVs for Pia, Pit, Pib, Pii, Pi3, Pi5(t), Pik-s, Piz, Piz-t, Piz-5, Pita-2, Pil2(t), $P i 19(\mathrm{t})$, and $P i 20(\mathrm{t})$. Thus, pathogenicity studies for blast disease have been conducted in southern Vietnam and the south central coast region of Vietnam, but they have not yet been conducted in northern Vietnam or other areas of central Vietnam.

In this study, the pathogenicities of blast isolates and variations of races in northern and central Vietnam were clarified by using monogenic lines (Tsunematsu et al. 2000) and LTH NILs (TelebancoYanoria et al. 2010) as well as the designation system developed by Hayashi and Fukuta (2009). The blast races were then characterized by comparing them with races determined in previous studies in Vietnam and other countries in Asia and Africa. Moreover, the first differential system in Vietnam was developed through the selection of SDBIs.

\section{Materials and Methods}

Collection of blast isolates. Isolates of rice blast (P. oryzae Cavara) were collected from leaves or panicles of infected rice plants in rain-fed lowland and irrigated lowland of six regions of northern and central Vietnam (northeast, northwest, Red River Delta, north central coast, south central coast, and central highlands) from 2012 to 2016 (Fig. 1 and Supplementary Table S1). Only one sample from one field or each cultivar was collected at investigation site to avoid duplication in the field survey.

Single spores were obtained from infected leaves or panicles and incubated on moist filter paper in a petri dish at room temperature for $24 \mathrm{~h}$ by the method of Hayashi et al. (2009). Colonies were grown on rice flour agar and stored on filter paper for repeat access to the same isolates.

DVs. For the pathological evaluation of the blast isolates collected, we used a set of 25 DVs carrying 23 resistance genes. This set of DVs included 23 monogenic lines for resistance genes Pish, Pib, Pit, Pia, Pii, Pi3, Pi5(t), Pik-s, Pik-m, Pil, Pik-p, Pi7(t), Pi9(t), Piz, Piz-5, Pizt, Pita-2, Pita, Pi12(t), Pi19(t), and Pi20(t) (Tsunematsu et al. 2000) and 2 NILs for Pik-h and Pik (Telebanco-Yanoria et al. 2010) with

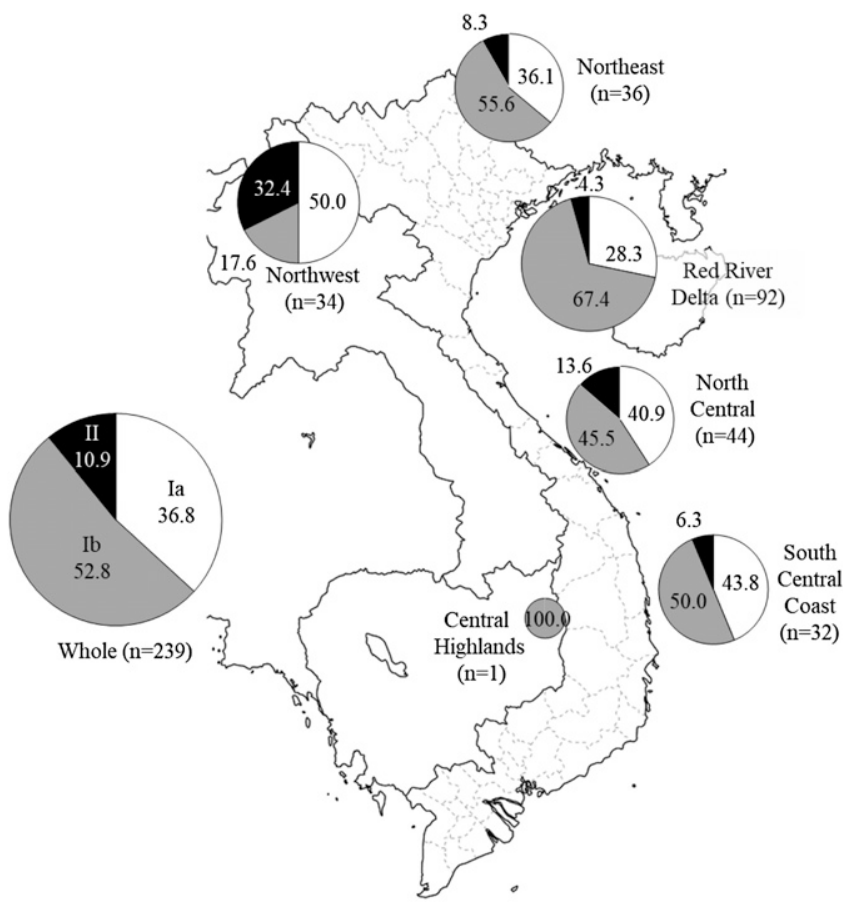

Fig. 1. Distribution of blast isolates classified into three cluster groups. A total of 239 blast isolates were collected from the northern and central regions of Vietnam and classified into three cluster groups (la, lb, and II) based on the reaction patterns to differential varieties and susceptible control cultivar Lijiangxintuanheigu. the LTH genetic background. LTH was used as the susceptible control.

Inoculation and evaluation. The seeds of the $25 \mathrm{DVs}$ and LTH were surface sterilized, soaked for 2 to 3 days, and then, sown at three seeds to a cell in plastic trays $(5 \times 7$ cells of $16-\mathrm{mm}$ diameter $\times 25-\mathrm{mm}$ depth), which were then placed in a greenhouse. Each tray also contained LTH for susceptibility checking. Seedlings were inoculated by the method of Hayashi et al. (2009). The spore concentration was standardized to $1 \times 10^{5}$ spores per milliliter of sterile water. Plants were inoculated 3 weeks after sowing at the fourth to fifth leaf stage by spraying 15 to $20 \mathrm{ml}$ of spore suspension onto each tray from a fine atomizer. Inoculated plants were kept in a dew chamber at $25^{\circ} \mathrm{C}$ for 20 to $24 \mathrm{~h}$ and then, transferred to a greenhouse maintained at 25 to $30^{\circ} \mathrm{C}$. The degree of infection of each seedling was evaluated 7 days after inoculation as described below. The process of inoculation and evaluation was performed twice.

The blast lesions were evaluated on a scale of 0 to 5 , where $0=$ no evidence of infection; $1=$ brown specks $<0.5 \mathrm{~mm}$ in diameter and no sporulation; 2 = brown specks about 0.5 to $1 \mathrm{~mm}$ in diameter, necrosis limited to the area between the large veins of the leaf, and no sporulation; $3=$ small eyespot lesions $<1.5$ times the interval between large veins or $<1.5 \mathrm{~mm}$ in diameter surrounded by dark brown and lesions capable of sporulation; $4=$ intermediate size eyespot lesions less than twice the interval between large veins or $\leq 2 \mathrm{~mm}$ in diameter; and $5=$ large eyespot lesions more than twice the interval between large veins or $>2 \mathrm{~mm}$ in diameter. According to the method of Hayashi and Fukuta (2009), lines were considered resistant when rated 0 to 2 and susceptible when rated 3 to 5, with the exception of the line IRBLsh-B for Pish (resistant $=0$ to 3), the line IRBLta2-Pi for Pita-2 (resistant = 0 to 3), and the line IRBL5-M for Pi5(t) (resis$\operatorname{tant}=0$ to 1$)$.

Race designation. Virulent blast isolates were designated by using the reaction patterns of the $25 \mathrm{DVs}$ and LTH following the system proposed by Hayashi and Fukuta (2009). The DVs were categorized into five groups: U (LTH and four DVs possessing Pia, Pish, Pib, and $P i t$ ), i (three DVs possessing Pii, Pi3, and Pi5(t), with the Pii locus on chromosome 9), k (seven DVs possessing Pik-s, Pik-m, Pil, $P i k-h, P i k, P i k-p$, and $P i 7(\mathrm{t})$, with the Pik region on chromosome 11), z (four DVs possessing Pi9(t), Piz, Piz-5, and Piz-t, with the $P i z$ region on chromosome 6), and ta (seven DVs possessing Pita2(Re), Pita-2(Pi), Pi12(t), Pita(K1), Pita(CP1), Pi19(t), and Pi20(t), with the Pita region on chromosome 12). In the groups i, $\mathrm{k}, \mathrm{z}$, and ta, multiple-allele genes or resistance genes located in the same chromosome regions were included. The other four genes are located in different regions (Pia on chromosome 11, Pish and Pit on chromosome 1, and $P i b$ on chromosome 2) and were placed in group U with LTH. We replaced lines IRBLkh-K3 and IRBLkKa with two LTH NILs (IRBLkh-K3[LT] and IRBLk-Ka[LT], respectively).

These groups consisted of one to three units with one to three DVs (genes) allocated to each unit. The codes 1,2, and 4 were allocated for each DV in each unit showing a susceptible reaction to the blast isolates. Blast races were designated by the combination of the codes representing the reactions of the DVs in each unit using the method of Gilmour (1973). Isolates classified this way were designated as "reaction type" within each DV group and "races" using the set of all five reaction types, which corresponded with the five DV groups.

Classification of blast isolates. The reaction scores of blast isolates with respect to the $25 \mathrm{DV}$ s and LTH were used for classification by cluster analysis. The cluster groups were characterized by the frequencies of virulent blast isolates to the DVs and LTH. The classification was performed by using Ward's hierarchical clustering method (Ward 1963) in JMP v.7.0.2 software (SAS Institute, Inc.). The relationships between the virulence of the cluster groups and the regions where the samples were collected were evaluated to determine the geographic distributions of each blast race.

Diversity of blast isolates. The diversity of blast isolates in each cluster group was evaluated by Simpson's diversity index (Simpson 1949). The index value varies from 0 to 1 , where $0=$ no diversity and 1 = maximum diversity. 


\section{Results}

Frequencies of blast isolates virulent toward DVs. A total of 239 isolates of rice blast ( $P$. oryzae Cavara) were collected from leaves or panicles of infected rice plants in six regions of northern and central Vietnam from 2012 to 2016: northeast $(n=36)$, northwest $(n=34)$, Red River Delta $(n=92)$, north central coast $(n=44)$, south central coast $(n=32)$, and central highlands $(n=1)$ (Fig. 1, Supplementary Table S1). Among them, 174 isolates were collected from irrigated lowland rice fields. The other 65 isolates were from rainfed lowland rice fields, with 15 of them collected from terraced rice fields in high-elevation areas.

These blast isolates showed different frequencies of virulence toward the 25 DVs and LTH, varying from 2.9 to $100.0 \%$ (Fig. 1, Supplementary Table S1). All blast isolates were virulent toward the susceptible variety LTH. The frequencies of blast isolates virulent toward the 12 DVs for Pia, Pib, Pit, Pik-s, Piz, Piz-t, Pii, Pi3, Pi5(t), $P i 19(\mathrm{t}), P i 12(\mathrm{t})$, and $P i 20(\mathrm{t})$ were high, ranging in value from 55.2 to $94.1 \%$. In contrast, the frequencies of blast isolates virulent toward the six DVs for Pish, Pik-m, Pik-h, Pil, Pi9(t), and Pita-2(Pi) were quite low $(<6.0 \%)$, and the frequencies of blast isolates virulent toward the other seven DVs for Pik, Pik-p, Pi7(t), Piz-5, Pita-2(Re),

Table 1. Relationship between ecosystems and cluster groups of blast isolates

\begin{tabular}{lrrrr}
\hline & \multicolumn{4}{c}{ No. of blast isolates (\%) } \\
\cline { 2 - 4 } Ecosystem & \multicolumn{3}{c}{ Cluster group } & \multicolumn{1}{c}{ Total } \\
\cline { 2 - 4 } & Ia & \multicolumn{1}{c}{ Ib } & II & $174(100.0)$ \\
Irrigated lowland & $62(35.6)$ & $102(58.6)$ & $10(5.7)$ & $65(100.0)$ \\
Rain-fed lowland & $26(40.0)$ & $23(35.4)$ & $16(24.6)$ & \\
Total & $88(36.8)$ & $125(52.3)$ & $26(10.9)$ & $239(100.0)$ \\
\hline
\end{tabular}

and Pita (two lines) showed intermediate values ranging from 6.3 to $23.4 \%$.

Classification of blast isolates. Based on the reaction patterns of the DVs and LTH, the blast isolates were classified into two major cluster groups (clusters I and II), with cluster I divided again into subclusters Ia and Ib (Fig. 1 and Supplementary Fig. S1). A total of 88 isolates $(36.8 \%)$ were categorized into cluster Ia, 125 (52.3\%) were categorized into cluster $\mathrm{Ib}$, and $26(10.9 \%)$ were categorized into cluster II. Several differences in the frequencies of virulent isolates were evident between these clusters. Remarkable differences in virulent blast isolates were found in the reactions of the $14 \mathrm{DVs}$ for Pikm, Pil, Pik-h, Pik, Pik-p, Pi7(t), Pi9(t), Piz, Piz-5, Piz-t, Pita-2 (two lines), and Pita (two lines) between clusters I and II. Blast isolates in cluster II showed higher frequencies of virulence toward 13 of these DVs, but that for the DV for Piz-t was lower than that of cluster I. There were remarkable differences between clusters $\mathrm{Ia}$ and $\mathrm{Ib}$ in the reactions of the seven DVs for Pib, Pit, Pia, Pii, Pi3, Pi5(t), and $P i z-t$. The frequencies of isolates virulent toward these DVs were higher in $\mathrm{Ib}$ than in Ia.

Thus, in Vietnam, dramatic differentiations of blast isolates were basically found in the reactions of DV groups $\mathrm{k}, \mathrm{z}$, and ta, and minor differentiations were found in DV groups $U$ and $i$.

Geographical distribution of cluster groups. Blast isolates in each of the three cluster groups were found in all regions except central highland, where only one isolate was collected, but the frequencies of isolates in these clusters varied among the five remaining regions (northeast, northwest, Red River Delta, north central, and south central coast) in Vietnam (Fig. 1). In the three regions of northeast, north central, and south central coast, the frequencies of isolates in cluster Ia varied from 36.1 to $43.8 \%$, frequencies in Ib were from 45.5 to $55.6 \%$, and frequencies in II were from 6.3 to $13.6 \%$; these frequencies were similar to those of the whole collection of isolates. The frequencies of isolates in the other two regions-Red River

Table 2. Reaction types in each cluster group

\begin{tabular}{|c|c|c|c|c|c|c|c|c|c|c|c|c|c|}
\hline \multirow[b]{3}{*}{ Reaction type } & \multicolumn{9}{|c|}{ Reaction types in each differential variety group } & \multicolumn{4}{|c|}{ No. of virulent isolates $(\%)$} \\
\hline & \multicolumn{9}{|c|}{ Differential or susceptible variety } & \multicolumn{4}{|c|}{ Cluster group } \\
\hline & Pish & $P i b$ & Pit & $\mathrm{LTH}^{\mathrm{z}}$ & Pia & - & - & - & - & $\begin{array}{l}\text { Ia, } n=88 \\
\quad(36.8)\end{array}$ & $\begin{array}{l}\mathrm{Ib}, n=125 \\
\quad(52.3)\end{array}$ & $\begin{array}{l}\text { II, } n=26 \\
\quad(10.9)\end{array}$ & $\begin{array}{l}\text { Total, } n=239 \\
\quad(100.0)\end{array}$ \\
\hline U63 & a & $\mathrm{v}$ & $\mathrm{v}$ & $\mathrm{v}$ & $\mathrm{v}$ & - & - & - & - & $56(29.9)$ & $110(58.8)$ & $21(11.2)$ & $187(100.0)$ \\
\hline Others & \multicolumn{9}{|c|}{ U01, U03, U21, U23, U43, U61, U71, U73 } & $32(61.5)$ & $15(28.8)$ & $5(9.6)$ & $52(100.0)$ \\
\hline Diversity index & & & & & & & & & & 0.56 & 0.22 & 0.33 & 0.38 \\
\hline Reaction type & Pii & $P i 3$ & $P i 5(\mathrm{t})$ & - & - & - & - & - & - & Ia & $\mathrm{Ib}$ & II & Total \\
\hline i7 & $\mathrm{v}$ & $\mathrm{v}$ & $\mathrm{v}$ & - & - & - & - & - & - & $33(20.1)$ & $111(67.7)$ & $20(12.2)$ & $164(100.0)$ \\
\hline Others & \multicolumn{9}{|c|}{ i0, i1, i2, i3, i4, i5, i6 } & $55(73.3)$ & 14 (18.7) & $6(8.0)$ & $75(100.0)$ \\
\hline Diversity index & & & & & & & & & & 0.78 & 0.21 & 0.39 & 0.51 \\
\hline Reaction type & Pik-s & - & - & Pik-m & Pil & $\begin{array}{c}\text { Pik- } \\
h\end{array}$ & Pik & Pik-p & $P i 7(\mathrm{t})$ & Ia & $\mathrm{Ib}$ & II & Total \\
\hline k100 & $\mathrm{v}$ & - & - & $\mathrm{a}$ & $\mathrm{a}$ & $\mathrm{a}$ & $\mathrm{a}$ & $\mathrm{a}$ & $\mathrm{a}$ & 67 (36.4) & $115(62.5)$ & $2(1.1)$ & $184(100.0)$ \\
\hline Others & \multicolumn{9}{|c|}{$\begin{array}{l}\mathrm{k} 000, \mathrm{k} 002, \mathrm{k} 003, \mathrm{k} 004, \mathrm{k} 005, \mathrm{k} 104, \mathrm{k} 102, \mathrm{k} 106, \mathrm{k} 107, \mathrm{k} 110, \mathrm{k} 116, \mathrm{k} 117, \\
\mathrm{k} 120, \mathrm{k} 126, \mathrm{k} 127, \mathrm{k} 137, \mathrm{k} 140, \mathrm{k} 167, \mathrm{k} 175, \mathrm{k} 176\end{array}$} & $21(38.2)$ & $10(18.2)$ & $24(43.6)$ & $55(100.0)$ \\
\hline Diversity index & & & & & & & & & & 0.41 & 0.15 & 0.88 & 0.40 \\
\hline Reaction type & $P i 9$ & - & - & Piz & $P i z-5$ & $\begin{array}{c}P i z- \\
t\end{array}$ & - & - & - & Ia & $\mathrm{Ib}$ & II & Total \\
\hline $\mathrm{z} 00$ & $\mathrm{a}$ & - & - & $\mathrm{a}$ & $\mathrm{a}$ & $\mathrm{a}$ & - & - & - & 19 (70.4) & $6(22.2)$ & $2(7.4)$ & $27(100.0)$ \\
\hline z01 & $\mathrm{a}$ & - & - & $\mathrm{v}$ & $\mathrm{a}$ & $\mathrm{a}$ & - & - & - & $25(43.1)$ & $25(43.1)$ & $8(13.8)$ & $58(100.0)$ \\
\hline z04 & $\mathrm{a}$ & - & - & $\mathrm{a}$ & $\mathrm{a}$ & $\mathrm{v}$ & - & - & - & $18(26.1)$ & $50(72.5)$ & $1(1.4)$ & $69(100.0)$ \\
\hline z05 & $\mathrm{a}$ & - & - & $\mathrm{v}$ & $\mathrm{a}$ & $\mathrm{v}$ & - & - & - & $20(39.2)$ & $29(56.9)$ & $2(3.9)$ & $51(100.0)$ \\
\hline Others & \multicolumn{9}{|c|}{ z02, z03, z06, z07, z11, z12, z13, z14, z15, z16, z17 } & $6(17.6)$ & $15(44.1)$ & $13(38.2)$ & $34(100.0)$ \\
\hline Diversity index & & & & & & & & & & 0.78 & 0.74 & 0.85 & 0.80 \\
\hline Reaction type & $\begin{array}{l}\text { Pita- } \\
2(P i)\end{array}$ & $\begin{array}{l}\text { Pita- } \\
2(R e)\end{array}$ & $\operatorname{Pi12}(\mathrm{t})$ & $\begin{array}{l}\text { Pita } \\
(K 1)\end{array}$ & $\begin{array}{l}\text { Pita } \\
(C P 1)\end{array}$ & - & $\operatorname{Pi19}(\mathrm{t})$ & $P i 20(\mathrm{t})$ & - & Ia & $\mathrm{Ib}$ & II & Total \\
\hline ta403 & a & a & $\mathrm{v}$ & $\mathrm{a}$ & a & - & $\mathrm{v}$ & $\mathrm{v}$ & - & $35(30.2)$ & $74(63.8)$ & $7(6.0)$ & $116(100.0)$ \\
\hline Others & \multicolumn{9}{|c|}{$\begin{array}{l}\text { ta000, ta001, ta002, ta003, ta010, ta012, ta } 013, \text { ta } 021, \text { ta } 022, \text { ta } 023, \text { ta } 030, \\
\text { ta031, ta032, ta200, ta201, ta203, ta213, ta222, ta223, ta333, ta } 401, \text { ta } 402, \\
\text { ta } 411, \text { ta } 413, \text { ta } 421, \text { ta } 422, \text { ta } 423, \text { ta } 430, \text { ta } 431, \text { ta } 433, \text { ta } 602, \text { ta603, ta613, } \\
\text { ta623, ta631, ta632, ta700, ta702, ta713, ta722, ta731, ta733 }\end{array}$} & $53(43.1)$ & $51(41.5)$ & $19(15.4)$ & $123(100.0)$ \\
\hline Diversity index & & & & & & & & & & 0.80 & 0.64 & 0.86 & 0.75 \\
\hline
\end{tabular}

\footnotetext{
${ }^{\mathrm{z}}$ a: avirulent, v: virulent, -: not applicable.
} 
Delta and northwest-were different from them. The frequencies of isolates in cluster groups Ia, Ib, and II in Red River Delta were 28.3, 67.4 , and $4.3 \%$, respectively; the frequencies in cluster Ia were lower than those of the whole collection, and the frequencies in cluster Ib were higher. In contrast, the frequencies of isolates in cluster groups $\mathrm{Ia}, \mathrm{Ib}$, and II in northwest were 50.0, 17.6, and $32.4 \%$, respectively; frequencies of isolates in clusters Ia and II were higher and frequencies in cluster Ib were lower compared with the whole collection. Thus, variations of blast isolates with respect to region were found in Vietnam, with dramatic differences found in the two regions northwest and Red River Delta.

Relationship between ecosystems and cluster groups. The frequencies of three cluster groups were different between irrigated lowland and rain-fed lowland (Table 1, Supplementary Table S1). The 174 blast isolates from irrigated lowland were categorized into three cluster groups: Ia (62 isolates, $35.6 \%$ ), Ib (102 isolates, $58.6 \%$ ), and II (10 isolates, 5.7\%). The frequencies of clusters Ib and II were higher and lower, respectively, than those of the whole collection. In contrast, the 65 blast isolates form rain-fed lowland were divided into clusters Ia (26 isolates, 40.0\%), Ib (23 isolates, $35.4 \%$ ), and II (16 isolates, $24.6 \%$ ). The frequencies of clusters $\mathrm{Ib}$ and II were lower and higher, respectively, than those of the whole collection.

Reaction types and races. The reaction types of the 239 blast isolates based on their virulence toward DV groups showed unique variations among the three cluster groups, and the Simpson's diversity index (Simpson 1949) varied from 0.38 to 0.80 (Table 2).

In DV group $\mathrm{U}$, blast isolates were classified into nine reaction types (U01, U03, U21, U23, U43, U61, U63, U71, and U73) based on the reactions to DVs for Pish, Pib, Pit, LTH, and Pia. Among these nine reaction types, U63 included 187 blast isolates (78.2\%), but the other types included few isolates. U63 was virulent toward the three DVs for Pib, Pit, and Pia as well as LTH to make it the dominant reaction type. No remarkable differences in these frequencies were found among the three cluster groups. Simpson's diversity index (Simpson 1949) was 0.56 in cluster Ia, 0.22 in cluster Ib, 0.33 in cluster II, and 0.38 overall. The overall value in group $\mathrm{U}$ was the lowest among the five DV groups.

In DV group $i$, the blast isolates were classified into eight reaction types: i0, i1, i2, i3, i4, i5, i6, and i7 (Table 2). A total of 164 isolates were classified as reaction type i7 (virulent toward DVs for Pii, Pi3, and $P i 5(\mathrm{t}))$. The frequency of $i 7$ isolates in cluster Ia was $20.1 \%$, and the frequencies in the other two clusters (Ib and II) were 67.7 and $12.2 \%$, respectively, among them. The remaining 75 isolates were classified into the other seven reaction types, with a few isolates in each. The diversity indices of clusters Ia, Ib, II, and the whole collection of isolates were $0.78,0.21,0.39$, and 0.51 , respectively.

In DV group $\mathrm{k}$, the blast isolates were classified into 22 reaction types: k000, k002, k003, k004, k005, k100, k102, k104, k106, k107, k110, k116, k117, k120, k126, k127, k137, k140, k167, $\mathrm{k} 175, \mathrm{k} 176$, and k177. Among them, 184 isolates were categorized into k100, which was virulent toward only Pik-s. There were few blast isolates of the other 21 reaction types. The diversity indices of clusters $\mathrm{Ia}, \mathrm{Ib}, \mathrm{II}$, and the whole collection of isolates were 0.41 , $0.15,0.88$, and 0.40 , respectively. Cluster II was high frequency of reaction type k100 and high diversity compared with the other two clusters.

In DV group $z$, blast isolates were classified into 15 reaction types: z00, z01, z02, z03, z04, z05, z06, z07, z11, z12, z13, z14, z15, z16, and z17. Among them, z00 (avirulent toward all four DVs), z01 (virulent toward the DV for Piz), z04 (virulent toward the DV for Piz-t), and z05 (virulent toward the DVs for Piz and Piz-t) were found as major reaction types. The frequency of z04 in cluster $\mathrm{Ib}$ was higher than those in clusters Ia and II, and the frequency of z00 isolates in Ia was remarkably higher than those in the other clusters. The diversity indices of clusters $\mathrm{Ia}, \mathrm{Ib}$, II, and the whole collection of isolates were $0.78,0.74,0.85$, and 0.80 , respectively. These high frequencies of reaction type $\mathrm{z} 00$ and z04 were characterized as clusters $\mathrm{Ia}$ and $\mathrm{Ib}$, respectively.

In DV group ta, the blast isolates were classified into 43 reaction types. A total of 116 isolates were categorized into ta403 (virulent toward DVs for Pi12(t), Pi19(t), and Pi2O(t)), and it was found as a

Table 3. Selection of standard differential blast isolates from Vietnam

\begin{tabular}{|c|c|c|c|c|c|c|c|c|c|c|c|c|c|c|}
\hline \multirow[b]{3}{*}{$\begin{array}{l}\text { Entry } \\
\text { No. }\end{array}$} & \multirow{2}{*}{\multicolumn{4}{|c|}{ Standard differential blast isolates }} & \multicolumn{10}{|c|}{ Differential and susceptible variety } \\
\hline & & & & & \multicolumn{5}{|c|}{$\mathbf{U}$} & \multicolumn{3}{|c|}{$\mathbf{i}$} & \multicolumn{2}{|c|}{$\mathbf{k}$} \\
\hline & Race designation & $\begin{array}{l}\text { Cluster } \\
\text { group }\end{array}$ & $\begin{array}{c}\text { Sample } \\
\text { No. }\end{array}$ & Site collected & $\begin{array}{c}\text { IRBLsh- } \\
\text { B }\end{array}$ & $\begin{array}{c}\text { IRBLb- } \\
\text { B }\end{array}$ & $\begin{array}{l}\text { IRBLt- } \\
\text { K59 }\end{array}$ & $\mathbf{L T H}^{\mathbf{Z}}$ & $\begin{array}{c}\text { IRBLa- } \\
\text { A }\end{array}$ & $\begin{array}{l}\text { IRBLi- } \\
\text { F5 }\end{array}$ & $\begin{array}{c}\text { IRBL3- } \\
\text { CP4 }\end{array}$ & $\begin{array}{c}\text { IRBL5- } \\
\text { M }\end{array}$ & $\begin{array}{l}\text { IRBLks- } \\
\text { F5 }\end{array}$ & $\begin{array}{l}\text { IRBLkm- } \\
\text { Ts }\end{array}$ \\
\hline 1 & U63-i7-k177-z07-ta403 & II & I19 & Hanoi & a & $\mathrm{v}$ & $\mathrm{v}$ & $\mathrm{v}$ & $\mathrm{v}$ & $\mathrm{v}$ & $\mathrm{v}$ & $\mathrm{v}$ & $\mathrm{v}$ & $\mathrm{v}$ \\
\hline 2 & U43-i7-k177-z06-ta021 & II & I95 & Son La & a & $\mathbf{a}$ & $\mathrm{v}$ & $\mathrm{v}$ & $\mathrm{v}$ & $\mathrm{v}$ & $\mathrm{v}$ & $\mathrm{v}$ & $\mathrm{v}$ & $\mathrm{v}$ \\
\hline 3 & U23-i3-k102-z01-ta032 & Ia & I165 & Cao Bang & a & $\mathrm{v}$ & a & $\mathrm{v}$ & $\mathrm{v}$ & $\mathrm{v}$ & $\mathrm{v}$ & a & $\mathrm{v}$ & a \\
\hline 4 & U71-i4-k175-z02-ta702 & II & $\mathrm{I} 185$ & Quang Binh & $\mathrm{v}$ & $\mathrm{v}$ & $\mathrm{v}$ & $\mathrm{v}$ & a & a & a & $\mathrm{v}$ & $\mathrm{v}$ & $\mathrm{v}$ \\
\hline 5 & U63-i6-k100-z05-ta403 & Ia & I106 & Phu Tho & a & $\mathrm{v}$ & $\mathrm{v}$ & $\mathrm{v}$ & $\mathrm{v}$ & a & $\mathrm{v}$ & $\mathrm{v}$ & $\mathrm{v}$ & a \\
\hline 6 & U63-i5-k100-z05-ta403 & Ia & I118 & Thai Nguyen & a & $\mathrm{v}$ & $\mathrm{v}$ & $\mathrm{v}$ & $\mathrm{v}$ & $\mathrm{v}$ & $\mathbf{a}$ & $\mathrm{v}$ & $\mathrm{v}$ & a \\
\hline 7 & U63-i3-k104-z01-ta421 & Ia & I143 & Dien Bien & a & $\mathrm{v}$ & $\mathrm{v}$ & $\mathrm{v}$ & $\mathrm{v}$ & $\mathrm{v}$ & $\mathrm{v}$ & a & $\mathrm{v}$ & a \\
\hline 8 & U63-i7-k003-z12-ta433 & II & I 221 & Bac Can & a & $\mathrm{v}$ & $\mathrm{v}$ & $\mathrm{v}$ & $\mathrm{v}$ & $\mathrm{v}$ & $\mathrm{v}$ & $\mathrm{v}$ & a & a \\
\hline 9 & U63-i7-k167-z13-ta423 & II & I126 & Dien Bien & a & $\mathrm{v}$ & $\mathrm{v}$ & $\mathrm{v}$ & $\mathrm{v}$ & $\mathrm{v}$ & $\mathrm{v}$ & $\mathrm{v}$ & $\mathrm{v}$ & a \\
\hline 10 & U63-i7-k117-z00-ta613 & II & I128 & Dien Bien & a & $\mathrm{v}$ & $\mathrm{v}$ & $\mathrm{v}$ & $\mathrm{v}$ & $\mathrm{v}$ & $\mathrm{v}$ & $\mathrm{v}$ & $\mathrm{v}$ & $\mathrm{v}$ \\
\hline 11 & U63-i7-k137-z17-ta403 & II & I127 & Dien Bien & a & $\mathrm{v}$ & $\mathrm{v}$ & $\mathrm{v}$ & $\mathrm{v}$ & $\mathrm{v}$ & $\mathrm{v}$ & $\mathrm{v}$ & $\mathrm{v}$ & $\mathrm{v}$ \\
\hline 12 & U71-i4-k176-z04-ta722 & II & I186 & Quang Tri & $\mathrm{v}$ & $\mathrm{v}$ & $\mathrm{v}$ & $\mathrm{v}$ & a & a & a & $\mathrm{v}$ & $\mathrm{v}$ & $\mathrm{v}$ \\
\hline 13 & U63-i0-k175-z00-ta702 & II & I 201 & Quang Binh & a & $\mathrm{v}$ & $\mathrm{v}$ & $\mathrm{v}$ & $\mathrm{v}$ & a & a & a & $\mathrm{v}$ & $\mathrm{v}$ \\
\hline 14 & U63-i7-k102-z16-ta403 & $\mathrm{Ib}$ & I 45 & Ninh Binh & a & $\mathrm{v}$ & $\mathrm{v}$ & $\mathrm{v}$ & $\mathrm{v}$ & $\mathrm{v}$ & $\mathrm{v}$ & $\mathrm{v}$ & $\mathrm{v}$ & a \\
\hline 15 & U63-i0-k126-z05-ta623 & II & $\mathrm{I} 175$ & Ha Tinh & a & $\mathrm{v}$ & $\mathrm{v}$ & $\mathrm{v}$ & $\mathrm{v}$ & a & a & a & $\mathrm{v}$ & a \\
\hline 16 & U63-i7-k100-z12-ta222 & $\mathrm{Ib}$ & I113 & Vinh Phuc & a & $\mathrm{v}$ & $\mathrm{v}$ & $\mathrm{v}$ & $\mathrm{v}$ & $\mathrm{v}$ & $\mathrm{v}$ & $\mathrm{v}$ & $\mathrm{v}$ & a \\
\hline 17 & U63-i7-k100-z05-ta403 & $\mathrm{Ib}$ & I147 & Hoa Binh & a & $\mathrm{v}$ & $\mathrm{v}$ & $\mathrm{v}$ & $\mathrm{v}$ & $\mathrm{v}$ & $\mathrm{v}$ & $\mathrm{v}$ & $\mathrm{v}$ & a \\
\hline 18 & U63-i7-k127-z03-ta333 & II & I 246 & Quang Ngai & a & $\mathrm{v}$ & $\mathrm{v}$ & $\mathrm{v}$ & $\mathrm{v}$ & $\mathrm{v}$ & $\mathrm{v}$ & $\mathrm{v}$ & $\mathrm{v}$ & a \\
\hline 19 & U63-i7-k100-z05-ta602 & $\mathrm{Ib}$ & $\mathrm{I} 2 \mathrm{a}$ & Ha noi & a & $\mathrm{v}$ & $\mathrm{v}$ & $\mathrm{v}$ & $\mathrm{v}$ & $\mathrm{v}$ & $\mathrm{v}$ & $\mathrm{v}$ & $\mathrm{v}$ & a \\
\hline 20 & U63-i3-k100-z05-ta433 & Ia & I148 & Hoa Binh & a & $\mathrm{v}$ & $\mathrm{v}$ & $\mathrm{v}$ & $\mathrm{v}$ & $\mathrm{v}$ & $\mathrm{v}$ & a & $\mathrm{v}$ & a \\
\hline 21 & U63-i7-k100-z11-ta223 & $\mathrm{Ib}$ & I194 & Quang tri & a & $\mathrm{v}$ & $\mathrm{v}$ & $\mathrm{v}$ & $\mathrm{v}$ & $\mathrm{v}$ & $\mathrm{v}$ & $\mathrm{v}$ & $\mathrm{v}$ & a \\
\hline 22 & U61-i5-k102-z04-ta423 & Ia & $\mathrm{I} 140$ & Lai Chau & a & $\mathrm{v}$ & $\mathrm{v}$ & $\mathrm{v}$ & a & $\mathrm{v}$ & a & $\mathrm{v}$ & $\mathrm{v}$ & a \\
\hline 23 & U63-i7-k126-z07-ta413 & II & $\mathrm{I} 75$ & Thai Binh & a & $\mathrm{v}$ & $\mathrm{v}$ & $\mathrm{v}$ & $\mathrm{v}$ & $\mathrm{v}$ & $\mathrm{v}$ & $\mathrm{v}$ & $\mathrm{v}$ & a \\
\hline 24 & U63-i7-k110-z04-ta022 & $\mathrm{Ib}$ & I 219 & Bac Can & a & $\mathrm{v}$ & $\mathrm{v}$ & $\mathrm{v}$ & $\mathrm{v}$ & $\mathrm{v}$ & $\mathrm{v}$ & $\mathrm{v}$ & $\mathrm{v}$ & $\mathrm{v}$ \\
\hline \multirow[t]{2}{*}{25} & U63-i7-k106-z01-ta431 & II & I123 & Dien Bien & a & $\mathrm{v}$ & $\mathrm{v}$ & $\mathrm{v}$ & $\mathrm{v}$ & $\mathrm{v}$ & $\mathrm{v}$ & $\mathrm{v}$ & $\mathrm{v}$ & a \\
\hline & & & & & & & & & & & & \multicolumn{3}{|c|}{ (Continued on next page) } \\
\hline
\end{tabular}

${ }_{\mathrm{z}}$ LTH, cultivar Lijiangxintuanheigu. a: avirulent, v: virulent. Bold indicates the representative reaction of SDBI to DV. 
dominant type, whereas the other 42 reaction types had few isolates. The frequency of isolates of reaction type ta403 in cluster Ib was higher than those in clusters Ia and II. The diversity indices of clusters $\mathrm{Ia}, \mathrm{Ib}$, II, and the whole collection of isolates were $0.80,0.64,0.86$, and 0.75 , respectively.

Designation of race. Based on the analyses of the reaction types of the five DV groups U, i, k, z, and ta, the 239 tested blast isolates were categorized into 153 races (Supplementary Table S1). The most dominant blast race in Vietnam was U63-i7-k100-z04-ta403, which comprised 36 isolates, followed by the three blast races U63-i7-k100z05-ta403, U63-i7-k100-z01-ta403, and U63-i7-k100-z00-ta403 comprising 16, 12, and 6 isolates, respectively. Most of the other races comprised only a single isolate.

Selection of SDBIs. Based on the reactions of the 239 isolates from Vietnam with respect to the 25 DVs harboring 23 resistance genes and LTH, 26 SDBIs that showed specific reactions toward the DVs were selected (Table 3). These SDBIs can differentiate the 23 kinds of resistance genes in the DVs based on the reaction patterns.

\section{Discussion}

The frequencies of virulence of 239 blast isolates collected from northern and central Vietnam varied from 2.9 to $94.1 \%$ toward 25 DVs (23 monogenic lines [Tsunematsu et al. 2000] and two LTH NILs [Telebanco-Yanoria et al. 2010]) harboring 23 resistance genes (Fig. 1). All isolates (100\%) were virulent toward the susceptible variety $\mathrm{LTH}$. The frequencies of isolates virulent toward the $12 \mathrm{DV}$ s for Pib, Pit, Pia, Pii, Pi3, Pi5(t), Pik-s, Piz, Piz-t, Pi12(t), Pi19(t), and $P i 20(\mathrm{t})$ ranged in the high values from 55.2 to $94.1 \%$. In contrast, the frequencies of isolates virulent toward the other DVs for Pish, Pik-m, Pil, Pik-h, Pik, Pik-p, Pi7(t), Pi9(t), Piz-5, Pita-2(Pi), Pita2(Re), Pita(K1), and Pita (CP1) all showed low values of $<20 \%$. Nguyen et al. (2015) also found that frequencies of blast isolates virulent toward 14 monogenic lines (Tsunematsu et al. 2000) for Pib, Pit, Pia, Pii, Pi3, Pi5(t), Pik-s, Piz-t, Piz-5 (Pi2(t)), Pita-2 (Pi), Pita (CP1), Pi12(t), Pi19(t), and Pi20(t) varied from around 40 to $76 \%$ and that frequencies of blast isolates virulent toward 10 monogenic lines for Pish, Pik-m, Pil, Pik-h, Pik, Pik-p,Pi7(t),Pi9(t), Piz, and $P i t a(\mathrm{~K} 1)(P i 4(\mathrm{t}))$ were all $<30 \%$ in the south central coast region of Vietnam. Thus, the high frequencies of blast isolates virulent toward 11 DVs for Pib, Pit, Pia, Pii, Pi3, Pi5(t), Pik-s, Piz-t, Pi12(t), $P i 19(\mathrm{t})$, and $P i 20(\mathrm{t})$ and the low frequencies toward 9 DVs for Pish, Pik-m, Pil, Pik-h,Pik, Pik-p,Pi7(t),Pi9(t), and Pita(K1) were findings common to both this study and that of the south central coast. The results for the other four DVs for Piz, Piz-5, Pita-2(Pi), and Pita (CP1) differed between the two studies. Noda et al. (1999) showed that high frequencies of isolates were virulent toward the Japanese DVs for Pit, Pia, and Pik-s; that $38 \%$ of isolates were virulent toward DVs for Pii and Pita; and that isolates virulent toward DVs for Pish, $P i k-p$, and Piz- $t$ were not found in the Mekong River Delta region of Vietnam. These results indicated that, among these regions in Vietnam, high frequencies of blast isolates virulent toward DVs for Pit, Pia, and Pik-s and low to DVs for Pish and Pik-p were findings common to all three studies and that frequencies of blast isolates virulent toward DVs for Piz, Piz-5, Piz-t, Pita-2(Pi), and Pita (CP1) differed.

The blast isolates in this study were classified into two major clusters I $(n=213)$ and II $(n=26)$, which were divided by the reactions of Pik-m, Pi1, Pik, Pik-p, Pi7(t), Piz-5, and Pita. Cluster I was further divided into two subclusters, Ia and $\mathrm{Ib}$, divided by the reactions of Pib, Pit, Pia, Pii, Pi3, Pi5(t), and Piz-t (Fig. 1). In the northeast, north central coast, and south central coast regions, the patterns of frequencies of isolates in the three clusters were not so different, and they were similar to the patterns of frequencies for the collection as a whole. In contrast, the patterns of frequencies in each cluster differed in the northwest and Red River Delta regions. In the northwest region, the frequencies of isolates in clusters Ia and II were higher and the frequency in cluster Ib was lower than those of the other regions remarkably; in the Red River Delta region, the frequencies in clusters Ia and II were higher, and the frequency in cluster Ib was lower (Fig. 2). Thus, different patterns of blast isolates were found in the reactions of the 14 DVs for Pib, Pit, Pia, Pii, Pi3, Pi5(t), Pik-m, Pil, Pik, Pik-p, Pi7(t), Piz-t, Piz-5, and Pita, and dramatic

Table 3. (Continued from preceding page)

\begin{tabular}{|c|c|c|c|c|c|c|c|c|c|c|c|c|c|c|c|}
\hline \multicolumn{16}{|c|}{ Differential and susceptible variety } \\
\hline \multicolumn{5}{|c|}{$\mathbf{k}$} & \multicolumn{4}{|c|}{$\mathbf{z}$} & \multicolumn{7}{|c|}{ ta } \\
\hline $\begin{array}{l}\text { IRBL1- } \\
\text { CLL }\end{array}$ & $\begin{array}{c}\text { IRBLkh-K3 } \\
{[\mathrm{LT}]}\end{array}$ & $\begin{array}{c}\text { IRBLk-Ka } \\
\text { [LT] }\end{array}$ & $\begin{array}{c}\text { IRBLkp- } \\
\text { K60 }\end{array}$ & $\begin{array}{c}\text { IRBL7- } \\
\text { M }\end{array}$ & $\begin{array}{l}\text { IRBL9- } \\
\text { W }\end{array}$ & $\begin{array}{c}\text { IRBLz- } \\
\text { Fu }\end{array}$ & $\begin{array}{l}\text { IRBLz5- } \\
\text { CA-1 }\end{array}$ & $\begin{array}{l}\text { IRBLzt- } \\
\quad \mathrm{T}\end{array}$ & $\begin{array}{l}\text { IRBLta2- } \\
\text { Pi }\end{array}$ & $\begin{array}{c}\text { IRBLta2- } \\
\text { Re }\end{array}$ & $\begin{array}{c}\text { IRBL12- } \\
\text { M }\end{array}$ & $\begin{array}{l}\text { IRBLta- } \\
\text { K1 }\end{array}$ & $\begin{array}{l}\text { IRBL-ta- } \\
\text { CP1 }\end{array}$ & $\begin{array}{c}\text { IRBL19- } \\
\text { A }\end{array}$ & $\begin{array}{l}\text { IRBL20- } \\
\text { IR24 }\end{array}$ \\
\hline $\mathrm{v}$ & $\mathrm{v}$ & $\mathrm{v}$ & $\mathrm{v}$ & $\mathrm{v}$ & a & $\mathrm{v}$ & $\mathrm{v}$ & $\mathrm{v}$ & a & a & $\mathrm{v}$ & a & a & $\mathrm{v}$ & $\mathrm{v}$ \\
\hline $\mathrm{v}$ & $\mathrm{v}$ & $\mathrm{v}$ & $\mathrm{v}$ & $\mathrm{v}$ & a & a & $\mathrm{v}$ & $\mathrm{v}$ & a & a & a & a & $\mathrm{v}$ & $\mathrm{v}$ & a \\
\hline a & a & a & $\mathrm{v}$ & a & a & $\mathrm{v}$ & a & a & a & a & a & $\mathrm{v}$ & $\mathrm{v}$ & a & $\mathrm{v}$ \\
\hline $\mathrm{v}$ & $\mathrm{v}$ & $\mathrm{v}$ & $\mathrm{a}$ & $\mathrm{v}$ & $\mathrm{a}$ & a & $\mathrm{v}$ & a & $\mathrm{v}$ & $\mathrm{v}$ & $\mathrm{v}$ & $\mathrm{a}$ & $\mathrm{a}$ & $\mathrm{a}$ & $\mathrm{v}$ \\
\hline a & a & a & a & a & a & $\mathrm{v}$ & a & $\mathrm{v}$ & $\mathrm{a}$ & $a$ & $\mathrm{v}$ & $\mathrm{a}$ & $\mathrm{a}$ & $\mathrm{v}$ & $\mathrm{v}$ \\
\hline $\mathrm{a}$ & $\mathrm{a}$ & $\mathrm{a}$ & $\mathrm{a}$ & $\mathrm{a}$ & $\mathrm{a}$ & $\mathrm{v}$ & $\mathrm{a}$ & $\mathrm{v}$ & $a$ & $\mathrm{a}$ & $\mathrm{v}$ & $a$ & $\mathrm{a}$ & $\mathrm{v}$ & $\mathrm{v}$ \\
\hline $\mathrm{a}$ & $a$ & $\mathrm{a}$ & $a$ & $\mathrm{v}$ & $\mathrm{a}$ & $\mathrm{v}$ & $a$ & $\mathrm{a}$ & $a$ & $a$ & $\mathrm{v}$ & $a$ & $\mathrm{v}$ & $\mathrm{v}$ & $\mathrm{a}$ \\
\hline $\mathrm{a}$ & $a$ & $\mathrm{v}$ & $\mathrm{v}$ & $\mathrm{a}$ & $\mathrm{v}$ & $\mathrm{a}$ & $\mathrm{v}$ & $\mathrm{a}$ & $a$ & $a$ & $\mathrm{v}$ & $\mathrm{v}$ & $\mathrm{v}$ & $\mathrm{v}$ & $\mathrm{v}$ \\
\hline $\mathrm{v}$ & $\mathrm{v}$ & $\mathrm{v}$ & $\mathrm{v}$ & $\mathrm{v}$ & $\mathrm{v}$ & $\mathrm{v}$ & $\mathrm{v}$ & $\mathrm{a}$ & $\mathrm{a}$ & $\mathrm{a}$ & $\mathrm{v}$ & $a$ & $\mathrm{v}$ & $\mathrm{v}$ & $\mathrm{v}$ \\
\hline $\mathbf{a}$ & $a$ & $\mathrm{v}$ & $\mathrm{v}$ & $\mathrm{v}$ & $\mathrm{a}$ & $\mathrm{a}$ & $a$ & $\mathrm{a}$ & $\mathrm{a}$ & $\mathrm{v}$ & $\mathrm{v}$ & $\mathrm{v}$ & $\mathrm{a}$ & $\mathrm{v}$ & $\mathrm{v}$ \\
\hline $\mathrm{v}$ & $\mathbf{a}$ & $\mathrm{v}$ & $\mathrm{v}$ & $\mathrm{v}$ & $\mathrm{v}$ & $\mathrm{v}$ & $\mathrm{v}$ & $\mathrm{v}$ & $\mathrm{a}$ & $\mathrm{a}$ & $\mathrm{v}$ & $a$ & $\mathrm{a}$ & $\mathrm{v}$ & $\mathrm{v}$ \\
\hline $\mathrm{v}$ & $\mathrm{v}$ & $\mathbf{a}$ & $\mathrm{v}$ & $\mathrm{v}$ & $\mathrm{a}$ & $\mathrm{a}$ & $\mathrm{a}$ & $\mathrm{v}$ & $\mathrm{v}$ & $\mathrm{v}$ & $\mathrm{v}$ & $\mathrm{a}$ & $\mathrm{v}$ & $a$ & $\mathrm{v}$ \\
\hline $\mathrm{v}$ & $\mathrm{v}$ & $\mathrm{v}$ & $\mathbf{a}$ & $\mathrm{v}$ & $\mathrm{a}$ & $\mathrm{a}$ & $\mathrm{a}$ & a & $\mathrm{v}$ & $\mathrm{v}$ & $\mathrm{v}$ & $\mathrm{a}$ & $\mathrm{a}$ & $\mathrm{a}$ & $\mathrm{v}$ \\
\hline $\mathrm{a}$ & $a$ & $\mathrm{a}$ & $\mathrm{v}$ & $\mathbf{a}$ & $\mathrm{v}$ & $\mathrm{a}$ & $\mathrm{v}$ & $\mathrm{v}$ & $\mathrm{a}$ & $\mathrm{a}$ & $\mathrm{v}$ & $a$ & $\mathrm{a}$ & $\mathrm{v}$ & $\mathrm{v}$ \\
\hline $\mathrm{v}$ & $a$ & $\mathrm{a}$ & $\mathrm{v}$ & $\mathrm{v}$ & $\mathbf{a}$ & $\mathrm{v}$ & $a$ & $\mathrm{v}$ & $a$ & $\mathrm{v}$ & $\mathrm{v}$ & $\mathrm{a}$ & $\mathrm{v}$ & $\mathrm{v}$ & $\mathrm{v}$ \\
\hline $\mathrm{a}$ & $\mathrm{a}$ & $\mathrm{a}$ & $\mathrm{a}$ & $\mathrm{a}$ & $\mathrm{v}$ & $\mathbf{a}$ & $\mathrm{v}$ & $\mathrm{a}$ & $\mathrm{a}$ & $\mathrm{v}$ & $\mathrm{a}$ & $\mathrm{a}$ & $\mathrm{v}$ & $\mathrm{a}$ & $\mathrm{v}$ \\
\hline $\mathrm{a}$ & $\mathrm{a}$ & $\mathrm{a}$ & $a$ & $\mathrm{a}$ & $a$ & $\mathrm{v}$ & $\mathbf{a}$ & $\mathrm{v}$ & $a$ & $a$ & $\mathrm{v}$ & $a$ & $\mathrm{a}$ & $\mathrm{v}$ & $\mathrm{v}$ \\
\hline $\mathrm{v}$ & $a$ & $\mathrm{v}$ & $\mathrm{v}$ & $\mathrm{v}$ & $\mathrm{a}$ & $\mathrm{v}$ & $\mathrm{v}$ & $\mathbf{a}$ & $\mathrm{v}$ & $\mathrm{v}$ & $\mathrm{a}$ & $\mathrm{v}$ & $\mathrm{v}$ & $\mathrm{v}$ & $\mathrm{v}$ \\
\hline $\mathrm{a}$ & $a$ & $\mathrm{a}$ & $\mathrm{a}$ & $\mathrm{a}$ & $\mathrm{a}$ & $\mathrm{v}$ & $\mathrm{a}$ & $\mathrm{v}$ & $\mathbf{a}$ & $\mathrm{v}$ & $\mathrm{v}$ & $a$ & $\mathrm{a}$ & $a$ & $\mathrm{v}$ \\
\hline $\mathrm{a}$ & $a$ & $\mathrm{a}$ & $\mathrm{a}$ & $\mathrm{a}$ & $\mathrm{a}$ & $\mathrm{v}$ & $a$ & $\mathrm{v}$ & $a$ & $\mathbf{a}$ & $\mathrm{v}$ & $\mathrm{v}$ & $\mathrm{v}$ & $\mathrm{v}$ & $\mathrm{v}$ \\
\hline $\mathrm{a}$ & $\mathrm{a}$ & $\mathrm{a}$ & $\mathrm{a}$ & $\mathrm{a}$ & $\mathrm{v}$ & $\mathrm{v}$ & $\mathrm{a}$ & $\mathrm{a}$ & $\mathrm{a}$ & $\mathrm{v}$ & $\mathbf{a}$ & $\mathrm{a}$ & $\mathrm{v}$ & $\mathrm{v}$ & $\mathrm{v}$ \\
\hline $\mathrm{a}$ & $a$ & $\mathrm{a}$ & $\mathrm{v}$ & $\mathrm{a}$ & $\mathrm{a}$ & $\mathrm{a}$ & $a$ & $\mathrm{v}$ & $a$ & $\mathrm{a}$ & $\mathrm{v}$ & $\mathbf{a}$ & $\mathrm{v}$ & $\mathrm{v}$ & $\mathrm{v}$ \\
\hline $\mathrm{v}$ & $\mathrm{a}$ & $\mathrm{a}$ & $\mathrm{v}$ & $\mathrm{v}$ & $\mathrm{a}$ & $\mathrm{v}$ & $\mathrm{v}$ & $\mathrm{v}$ & $a$ & $\mathrm{a}$ & $\mathrm{v}$ & $\mathrm{v}$ & $\mathbf{a}$ & $\mathrm{v}$ & $\mathrm{v}$ \\
\hline $\mathrm{a}$ & $\mathrm{a}$ & $\mathrm{a}$ & $\mathrm{a}$ & $\mathrm{a}$ & $\mathrm{a}$ & $\mathrm{a}$ & $\mathrm{a}$ & $\mathrm{v}$ & $\mathrm{a}$ & $\mathrm{a}$ & $\mathrm{a}$ & $\mathrm{a}$ & $\mathrm{v}$ & $\mathbf{a}$ & $\mathrm{v}$ \\
\hline $\mathrm{a}$ & $\mathrm{a}$ & $\mathrm{a}$ & $\mathrm{v}$ & $\mathrm{v}$ & $\mathrm{a}$ & $\mathrm{v}$ & $\mathrm{a}$ & $\mathrm{a}$ & $\mathrm{a}$ & $\mathrm{a}$ & $\mathrm{v}$ & $\mathrm{v}$ & $\mathrm{v}$ & $\mathrm{v}$ & $\mathbf{a}$ \\
\hline
\end{tabular}


changes in these patterns were found in the northwest and Red River Delta regions. The dominant reaction types of these blast isolates in Vietnam were U63, i7, k100, z00, z01, z04, z05, and ta403. Remarkable differences of frequencies between clusters I and II were found in the reaction types $\mathrm{k} 100, \mathrm{z} 04, \mathrm{z} 05$ and ta403, and remarkable differences of frequencies between clusters $\mathrm{Ia}$ and $\mathrm{Ib}$ were found in reaction types U63, i7, z00, and z01. We identified four major blast races, which accounted for $29.28 \%$ of all 239 isolates: U63-i7$\mathrm{k} 100-\mathrm{z} 04-\mathrm{ta} 403$ ( $15.1 \%$ of the whole set), U63-i7-k100-z05-ta403 (6.7\%), U63-i7-k100-z01-ta403 (5.0\%), and U63-i7-k100-z00ta403 (2.5\%). These results indicate that blast fungus strains virulent against Pib, Pit, Pia, Pii, Pi3, Pi5(t), Pik-s, Piz, Piz-t, Pi12(t), Pi19(t), and $P i 2 O(\mathrm{t})$ are distributed widely and together in Vietnam. Variation of blast races in Vietnam was mainly influenced by the reactions to DV groups $\mathrm{k}, \mathrm{z}$, and ta, and DV groups $\mathrm{U}$ and i played a minor role.

The variations of blast races in other regions of Vietnam and some other countries have also been clarified based on the reaction patterns of the same set of $25 \mathrm{DVs}$ and LTH. So far, this set of $25 \mathrm{DVs}$ and LTH has been utilized to investigate 94 blast isolates from the Mekong River Delta in southern Vietnam (Y. Fukuta, N. L. Lang, P. T. T. Ha, T. T. Luy, P. V. Du, N. Hayashi, A. Kawasaki-Tanaka, M. Obara, T. B. Toan, and B. C. Bu, unpublished data), 310 blast isolates collected from Japan (Kawasaki-Tanaka and Fukuta 2014), 331 blast isolates from Bangladesh (Khan et al. 2016), 122 blast isolates from Cambodia (Fukuta et al. 2014), and 96 blast isolates from West Africa (Odjo et al. 2014). The blast isolates collected from the Mekong River Delta showed high frequencies of virulence toward DVs for Pib, Pit, Pia, Pik-s, Piz-t, Pi12(t), Pi19(t), and Pi2O(t) in comparison with the other DVs. These results were similar to those from northern and central Vietnam found in this study, but high frequencies of DVs for Pii, Pi3, Pi5(t), and Piz were additionally shown. This means that reaction (virulence frequencies) isolates to DVs of $P i i, P i 3, P i 5(\mathrm{t})$, and Piz were different between the southern and the northern/central regions in Vietnam. In Cambodia, blast isolates were classified into two major clusters that were divided by the reaction (virulence frequencies) isolates to DVs of Pii, Pi3, Pi5(t), Pik-s, Pi12(t), Pita, and Pi20(t) (Fukuta et al. 2014). In Bangladesh, blast isolates were classified into two major clusters that were divided by the reaction (virulence frequencies) isolates to DVs of Pii, Pi3, Pi5(t), Pik-m, Pil, Pik-h, Pik, Pik-p, and Pi7(t) (Khan et al. 2016). In Japan, blast isolates were classified into two major clusters that were divided by the reactions of Pik-m, Pil, Pik-h,Pik, Pik-p, and $P i 7(\mathrm{t})$ (Kawasaki-Tanaka et al. 2016). In West Africa, blast isolates were classified into two major clusters that were divided by the reactions of Pik-m, Pil, Pik-h, Pik, Pita-2, and Pi2O(t) (Odjo et al. 2014). These results indicated that the reactions of DV groups $i, k$, and ta were the main factors in the variations of blast races, and the reaction group $\mathrm{k}$ was always found among them. In Vietnam, the reaction group $\mathrm{k}$ was also found as one of the main factors in the variations of blast races. These findings suggest that the reaction to DVs for group $\mathrm{k}$ is the main contributor to the variation of blast races, with reactions to other DVs for i, $\mathrm{z}$, and ta playing additional roles according to the particular situations of countries or regions. The frequency of cluster Ib in irrigated lowland was higher than that in rain-fed lowland, and that of cluster II in rain-fed lowland was higher than that in irrigated lowland (Table 1). Rice cultivars are grown on terraces in

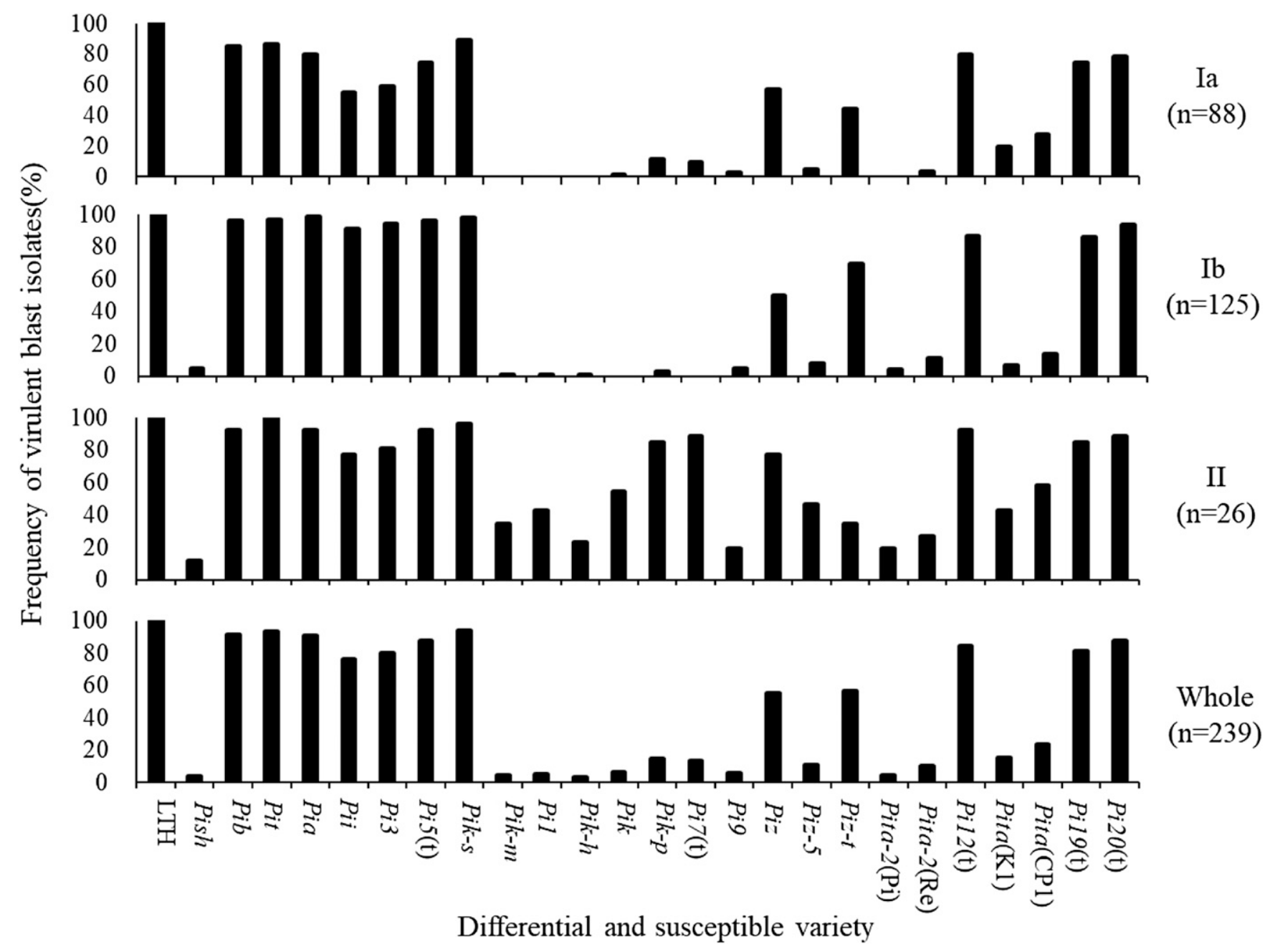

Fig. 2. Frequency of virulent blast isolates in each cluster group. A total of 239 blast isolates from Vietnam were investigated for pathogenicity against these differential varieties and a susceptible control cultivar Lijiangxintuanheigu (LTH). A total of 23 monogenic lines (Tsunematsu et al. 2000) and 2 near-isogenic lines with the genetic background of LTH (Telebanco-Yanoria et al. 2010) were used as the differential varieties. 
the high mountainous areas of the northwest region, and different cultivars are grown in the low-altitude lowlands of the Red River Delta region. These geographical conditions, ecosystems, and the rice cultivars that are adapted to each region might account for the variations of blast isolates in the northwest and Red River Delta regions. The interaction between host resistance and blast fungus virulence can be explained by the gene-for-gene theory: every resistance gene in the host corresponds to an avirulence gene in the pathogen (Flor 1971; Silué et al. 1992). To clarify the relationships between blast races and resistance genes in rice cultivars and develop the durable protection system, it will be necessary to clarify the genetic variation of resistance in Vietnamese rice cultivars in each region.

This is the first study on the diversity and distribution of blast races in the wide area stretching from northern to central Vietnam using the set of DVs of monogenic lines and NILs of LTH (Telebanco-Yanoria et al. 2010; Tsumematsu et al. 2000). However, blast isolates from southern Vietnam, including the Mekong River Delta region, have yet not been evaluated. It will be necessary to collect and investigate isolates from and compare results between the three regions of north, central, and south Vietnam to more completely clarify the differentiations of blast races and access development for a stable protection system in each region.

A set of SDBIs was selected by the designation system of Hayashi and Fukuta (2009) (Table 3). These SDBIs plus DVs, such as monogenic lines (Tsumematsu et al. 2000) and LTH NILs (Telebanco-Yanoria et al. 2010), will be used as the first differential system in Vietnam. The SDBIs were selected based on the differentiation ability by avirulent to fewer number of resistance genes and the sporulating ability from middle to high numbers, but the stability during long storage was not considered yet. The SDBIs will be used as the first basic set, and the representative isolates will need to changed according to the modifications of abilities or stabilities of virulence.

\section{Acknowledgments}

This study was performed as part of a series of JIRCAS research projects "Blast Research Network for Stable Rice Production" (2006 to 2010) and "Rice Innovation for Environmentally Sustainable Production Systems" (2011 onward).

\section{Literature Cited}

Flor, H. H. 1971. Current status of the gene-for-gene concept. Annu. Rev. Phytopathol. 9:275-296.

Fukuta, Y., Koga, I., Ung, T., Sathya, K., Kawasaki-Tanaka, A., Koide, Y., Kobayashi, N., Obara, M., Yadana, H., and Hayashi, N. 2014. Pathogenicity of rice blast (Pyricularia oryzae Cavara) isolates from Cambodia. JARQ 48:155-166. Gilmour, J. 1973. Octal notation for designating physiologic races of plant pathogens. Nature 242:620.
Hayashi, N., and Fukuta, Y. 2009. Pages 11-15 in: Proposal for a new international system of differentiating races of blast (Pyricularia oryzae Cavara) by using LTH monogenic lines in rice (Oryza sativa L.). JIRCAS working report No. 63. Y. Fukuta, C. M. Vera Cruz, and N. Kobayashi, eds. Japan International Research Center for Agricultural Sciences, Tsukuba, Ibaraki, Japan.

Hayashi, N., Kobayashi, N., Vera Cruz, C. M., and Fukuta, Y. 2009. Pages 17-33 in: Protocols for the sampling of diseased specimens and evaluation of blast disease in rice. JIRCAS Working Report No. 63. Y. Fukuta, C. M. Vera Cruz, and N. Kobayashi, eds. Japan International Research Center for Agricultural Sciences, Tsukuba, Ibaraki, Japan.

Kawasaki-Tanaka, A., and Fukuta, Y. 2014. Genetic variation in resistance to blast disease (Pyricularia oryzae Cavara) in Japanese rice (Oryza sativa L.) as determined using a differential system. Breed. Sci. 64:183-192.

Kawasaki-Tanaka, A., Hayashi, N., Yanagihara, S., and Fukuta, Y. 2016. Diversity and distribution of rice blast (Pyricularia oryzae Cavara) races in Japan. Plant Dis. 100:816-823.

Khan, M. A. I., Ali, M. A., Monsur, M. A., Kawasaki-Tanaka, A., Hayashi, N., Yanagihara, S., Obara, M., Mia, M. A. T., Latif, M. A., and Fukuta, Y. 2016. Diversity and distribution of rice blast (Pyricularia oryzae Cavara) races in Bangladesh. Plant Dis. 100:2025-2033.

Kiyosawa, S. 1984. Establishment of differential varieties for pathogenicity test of rice blast fungus. Rice Genet. Newsl. 1:95-97.

Nguyen, T. T. T., Hai, T., Tiwn, N. L., and Nguyen, H. K. L. 2015. Identification of rice blast resistance genes in South Central Coast of Vietnam using monogenic lines under field condition and pathogenicity assays. J. Agr. Sci. Tech. A \& B 5: 491-500.

Noda, T., Hayashi, N., Du, P. V., Dinh, H. D., and Lai, E. V. 1999. Distribution of pathogenic races of rice blast fungus in Vietnam. Ann. Phytopathol. Soc. Jpn. 65:526-530.

Odjo, T., Kawasaki-Tanaka, A., Noda, T., Ahohuendo, B. C., Sere, Y., Kumashiro, T., Yanagihara, S., and Fukuta, Y. 2014. Pathogenicity analysis of blast (Pyricularia oryzae Cavara) isolates from West Africa. JARQ 48:403-412.

Sang, P. M., Mai, V., and Du, P. V. 1996. Proceedings of the International Workshop on Rice Disease Management Technologies in the Tropics. Malaysian Agricultural Research and Development Institute, Malaysia.

Silué, D., Notteghem, J. L., and Tharreau, D. 1992. Evidence of gene-for-gene relationship in the Oryza sativa-Magnaporthe grisea pathosystem. Phytopathology 82:577-580.

Simpson, E. H. 1949. Measurement of diversity. Nature 163:688.

Telebanco-Yanoria, M. J., Koide, Y., Fukuta, Y., Imbe, T., Kato, H., Tsunematsu, H., and Kobayashi, N. 2010. Development of near-isogenic lines of Japonicatype rice variety Lijiangxintuanheigu as differentials for blast resistance. Breed. Sci. 60:629-638.

Tsunematsu, H., Yanoria, M. J. T., Ebron, L. A., Hayashi, N., Ando, I., Kato, H., Imbe, T., and Khush, G. S. 2000. Development of monogenic lines of rice for blast resistance. Breed. Sci. 50:229-234.

Ward, J. H. 1963. Hierarchical grouping to optimize an objective function. J. Am. Stat. Assoc. 58:236-244.

Zeigler, R. S., Tohme, J., Nelson, R., Levy, M., and Correa, F. 1994. Lineage exclusion: A proposed for linking blast population analysis to resistance breeding. Pages 267-292 in: Rice Blast Disease. R. S. Zeigler, S. A. Leong, and P. S. Teng, eds. IRRI \& CABI Publication, Wallingford, UK. 